\title{
Konseling kelompok analisis transaksional dalam Meningkatkan Keterampilan Komunikasi Interpersonal Mahasiswa
}

\author{
Devi Permatasari*), \\ Universitas Kanjuruhan Malang \\ *) Correspondence: devipermatasari@unikama.ac.id
}

\begin{abstract}
Sebagai makhluk sosial, setiap individu dipastikan melakukan komunikasi dengan orang lain. Oleh karena itu, komunikasi memegang peranan penting dalam kehidupan sehari-hari dan merupakan fungsi yang paling pokok dalam berinteraksi. Komunikasi juga penting bagi mahasiswa S1 Program Studi Bimbingan dan Konseling (BK) sebagai calon guru Bimbingan dan Konseling yang hendaknya mampu membangun keterampilan komunikasi interpersonal sedini mungkin. Penelitian ini bertujuan untuk mengetahui keefektifan konseling kelompok dengan teknik analisis transaksional dalam meningkatkan keterampilan komunikasi interpersonal pada Mahasiswa Bimbingan dan Konseling Universitas Kanjuruhan Malang angkatan 2015-2017 tahun akademik 2017/2018. Penelitian ini menggunakan rancangan eksperimen one-group pretest-postest dengan subjek 9 mahasiswa yang teridentifikasi sebagai mahasiswa yang memiliki keterampilan komunikasi interpersonal rendah. Alat ukur yang digunakan dalam penelitian ini yaitu skala keterampilan komunikasi interpersonal, yang dibuat oleh peneliti, skala ini sudah valid dan reliabel, sehingga dapat mengukur apa yang diukur. Hasil penelitian menunjukan bahwa ada perbedaan tingkat keterampilan komunikasi interpersonal mahasiswa sebelum dan sesudah mendapatkan intervensi konseling kelompok dengan teknik analisis transaksional. Data tersebut dianalisis dengan menggunakan uji statistic Wilcoxon. Intervensi konseling kelompok dengan teknik analisis transaksional dapat meningkatkan keterampilan komunikasi interpersonal mahasiswa.
\end{abstract}

Keywords: Komunikasi interpersonal, konseling kelompok, analisis transaksional, mahasiswa

Article History: Received on 07/12/2019; Revised on 20/01/2020; Accepted on 13/02/2020; Published Online: 02/03/2020.

\begin{tabular}{|c|c|}
\hline (c) (i) & $\begin{array}{l}\text { This is an open access article distributed under the Creative Commons Attribution License, which permits unrestricted use, } \\
\text { distribution, and reproduction in any medium, provided the original work is properly cited. } ₫ 2020 \text { by author. }\end{array}$ \\
\hline
\end{tabular}

Keterampilan komunikasi interpersonal merupakan keterampilan yang dimiliki individu untuk mengolah hubungan interpersonal dalam mengatur komunikasi (Gumilang, 2016). Komunikasi merupakan fondasi dari semua hubungan interpersonal, dan dalam kehidupan sehari hari yang dipenuhi oleh pengalaman komunikasi dengan orang lain (Nagarajan \& Dr.G.Wiselin, 2010). Sebagai makhluk sosial, setiap individu dipastikan melakukan komunikasi dengan orang lain (Maulana \& Hidayati, 2016). Oleh 
karena itu, komunikasi memegang peranan penting dalam kehidupan sehari-hari dan merupakan fungsi yang paling pokok dalam berinteraksi.

Berdasarkan temuan penelitian terdahulu keterampilan komunikasi interpersonal mendukung pentingnya kompetensi komunikatif dalam berbagai hubungan relasional, salah satunya keberhasilan dalam proses konseling (Hariko, 2017; Radjah, 2016; Riswanto et al., 2016; Simon, 2011). Secara khusus, dampak keterampilan mahasiswa atau calon Guru Bimbingan dan Konseling (BK) dalam berkomunikasi dengan konseli, berpengaruh pada diri calon Guru BK dalam membangun hubungan yang memuaskan dengan konseli (hubungan selain proses konseling), tetapi juga berpengaruh pada keberhasilan dalam proses konseling. Keterampilan komunikasi interpersonal bukan hanya keterampilan biasa (Huang \& Lin, 2018; Lopes et al., 2013), melainkan keterampilan yang harus dimiliki mahasiswa atau calon Guru BK (Hariko, 2017; Radjah, 2016).

Mahasiswa S1 Program Studi Bimbingan dan Konseling (BK) sebagai calon Guru BK, hendaknya mampu membangun keterampilan komunikasi interpersonal sedini mungkin (Qalbas, 2018). Keterampilan komunikasi interpersonal menjadi salah satu bagian dari kompetensi kepribadian yang harus dimiliki oleh Guru BK agar dapat memberikan layanan Bimbingan dan Konseling secara optimal (Irawan, 2017). Kompetensi kepribadian yang dimaksud, yaitu Guru BK mampu menampilkan kinerja yang berkualitas tinggi, salah satunya dengan berkomunikasi secara efektif.

Kinerja seorang Guru BK menuntut keterlibatan dalam interaksi sosial yang terwujud dalam hubungan Guru BK dengan konseli (Riswanto et al., 2016). Hubungan ini merupakan sebuah proses profesional yang melibatkan dua pihak yang secara bersamasama dan bersinergi, berusaha mencapai suatu tujuan bersama (Hariko, 2017). Konseling merupakan suatu tipe hubungan khusus antara Guru BK dengan orang yang membutuhkan bantuannya (konseli), yang dapat berbentuk melalui interaksi tatap muka, melalui telepon, surat-menyurat, ataupun dengan bantuan alat elektronik yang memiliki tujuan dari konseling itu sendiri (Geldard, 2005). Kualitas hubungan interaksi antara Guru BK dan konseli tampaknya paling memungkinkan untuk menciptakan pertumbuhan hubungan antar keduanya (Corey, 2015). Oleh karena itu, sebagai mahasiswa calon Guru BK hendaknya mampu membina hubungan baik dengan orang lain pada kehidupan sehari-hari sebagai bentuk latihan sebagai seorang Guru BK profesional (Hapsyah et al., 2019).

Calon Guru BK harus bekerja berdasarkan khasanah teoritik BK dan memiliki keterampilan komunikasi interpersonal yang baik sebagai seorang helping profession, yaitu: kemampuan mendengarkan apa yang disampaikan orang lain, kemampuan memahami orang lain, kemampuan mengkomunikasikan pikiran dan perasaan secara tepat dan jelas, kemampuan saling menerima dan saling memberi dukungan, dan kemampuan memecahkan konflik (Desai, 2018). Oleh karena itu, pendidikan S1 BK diharapkan dapat menjadi sarana dalam membangun keterampilan komunikasi interpersonal calon Guru BK yang profesional.

Melihat fenomena terjadi di kalangan mahasiswa calon Guru BK di Universitas Kanjuruhan Malang, bahwa seringnya terjadi konflik antar teman sehingga terbentuk beberapa kelompok dalam kelas. Selanjutnya, mahasiswa sering melontarkan kata makian kepada teman yang berpendapat tidak sesuai ketika dalam forum. Hal ini tidak 
hanya terjadi pada mahasiswa calon Guru BK, melainkan kasus seperti ini sudah mengglobal (terjadi pada mahasiswa Program Studi lain). Saat ini sering terjadi kasus kekerasan antara guru terhadap siswanya atau mahasiswa terhadap dosen (Palupi et al., 2016). Kekerasan yang terjadi bukan hanya berupa fisik melainkan secara verbal. Hal ini terjadi karena mahasiswa tersebut kurang memiliki keterampilan komunikasi interpersonal (Sukarno, 2017).

Kurangnya keterampilan komunikasi interpersonal dilingkungan mahasiswa juga dapat menimbulkan beberapa dampak negatif (Saaranen et al., 2015; Vahabi et al., 2017)seperti; sulit dalam berkomunikasi dengan teman, kurang sopan terhadap dosen, perselisihan atau pertengkaran antar teman, termasuk kurangnya keterampilan mendengarkan yang menimbulkan kurangnya pemahaman tentang materi yang disampaikan oleh dosen maupun informasi yang diberikan oleh dosen, bahkan karena kurangnya keterampilan komunikasi interpersonal, mahasiswa yang tidak paham, sulit mengemukakan pertanyaan terhadap dosen atau orang lain (Wijaya \& Naryoso, 2017), oleh karena itu, penelitian untuk mengentaskan masalah tersebut harus dilakukan.

Berdasarkan motif komunikasi interpersonal yang ditunjukkan mahasiswa calon Guru BK, perlu memiliki keterampilan komunikasi interpersonal yang baik. Dengan kata lain, penting bagi calon Guru BK menjadi terampil dalam berkomunikasi (Radjah, 2016; Riswanto et al., 2016). Mengingat komunikasi merupakan keterampilan yang paling utama harus dimiliki oleh seorang Guru BK (Astiti et al., 2018). Dalam memberikan pelayanan Bimbingan dan Konseling kepada konseli, seorang Guru BK harus benar-benar memahami apa yang menjadi masalah yang dialami konseli (Suprihatin, 2017). Melalui komunikasi dua pihak antara Guru BK dengan konseli, akan terjadi interaksi yang efektif apabila Guru BK dapat menunjukkan keterampilan komunikasinya dengan baik.

Layanan konseling kelompok dapat menjadi suatu strategi bantuan kepada siswa dalam membuat keputusan secara tepat dan diharapkan akan berdampak positif bagi siswa (Chen \& Rybak, 2017). Salah satunya Analisis Transaksional, atau disingkat AT, merupakan teori kepribadian dan sistem yang terorganisir dari terapi interaksional (Sundah, 2018). AT ini berakar pada filsafat antideterministik. Menempatkan iman dalam kapasitas individu untuk mengatasi kebiasaan pola dan untuk memilih tujuan-tujuan dan perilaku baru (Corey, 2009, 2015)

AT merupakan ancangan yang dilandasi perpaduan dari aspek kognitif dan perilaku dari proses terapeutik dan diamati melalui transaksi antar individu (Corey, 2009, 2015) Senada dengan pendapat (Corey, 2015) mengungkapkan bahwa konseling AT lebih menekankan aspek kognitif, rasional, dan behavioral tentang kepribadian serta berorientasi pada peningkatan kesadaran, sehingga konseli akan mampu membuat keputusan-keputusan dan rencana baru bagi kehidupannya.

Menciptakan interaksi yang harmonis antara kedua pihak dapat membuat kondisi emosi dan ego state seseorang dapat terkontrol dengan baik (Sari \& Widyastuti, 2016). Membentuk dan memelihara interaksi yang berkualitas dengan keluarga, teman, dan tergantung pada kemampuan individu bertransaksi dan bekerja dengan ego state yang sesuai untuk membuat individu mampu memiliki kemampuan berkomunikasi yang baik, 
serta lebih banyak menghargai dan menghormati orang lain melalui interaksi yang terjadi, oleh karena itu penelitian ini penting untuk dilakukan (Wulandari, 2019).

Keterampilan komunikasi interpersonal mahasiswa calon Guru BK ini dapat ditingkatkan menjadi lebih baik melalui konseling kelompok dengan pendekatan AT. AT merupakan teori kepribadian dan sistem yang terorganisir dari terapi interaksional (Permatasari, 2015). Melalui layanan konseling kelompok dapat menjadi suatu strategi bantuan kepada calon Guru BK dalam meningkatkan komunikasi interpersonalnya. Kelebihan dari penelitian ini adalah, subjek penelitian itu sendiri, yaitu mahasiswa calon Guru BK, yang harapannya menjadi Guru yang dapat mengentaskan masalah yang dialaminya kelak dengan komunikasi yang baik. Harapannya, penelitian ini dapat menjadi sumber rujukan untuk penelitian selanjutnya yang sejenis.

\section{Metode}

Penelitian ini merupakan penelitian Quasi Eksperiment, dengan menggunakan desain Pre-test dan Post-test Group (Creswell \& Creswell, 2017). Perlakuan yang diberikan yaitu dengan menggunakan konseling kelompok dengan teknik analisis transaksional untuk meningkatkan kemampuan komunikasi interpersonal mahasiswa calon Guru BK Teknik pengambilan sampel dalam penelitian ini menggunakan purposive sampling dimana dalam pengambilan sampel berdasarkan kriteria, siswa yang memiliki keterampilan komunikasi interpersonal rendah yang di peroleh dari hasil skala keterampilan komunikasi interpersonal, yang dibuat oleh peneliti, skala ini sudah valid dan reliabel, sehingga dapat mengukur apa yang diukur. Populasi penelitian ini adalah mahasiswa S1 Bimbingan dan Konseling Universitas Kanjuruhan Malang, angkatan 20152017 tahun akademik 2017/2018 yang berjumlah 234 mahasiswa. Dari populasi tersebut didapatkan subjek penelitian sejumlah 9 mahasiswa, yang memiliki keterampilan komunikasi interpersonal rendah. Analisis data yang digunakan dalam penelitian ini yaitu uji Wilcoxon Sign Rank Test.

\section{Hasil dan Pembahasan}

Teknik analisis transaksional dapat dilihat pada Gambar 1.

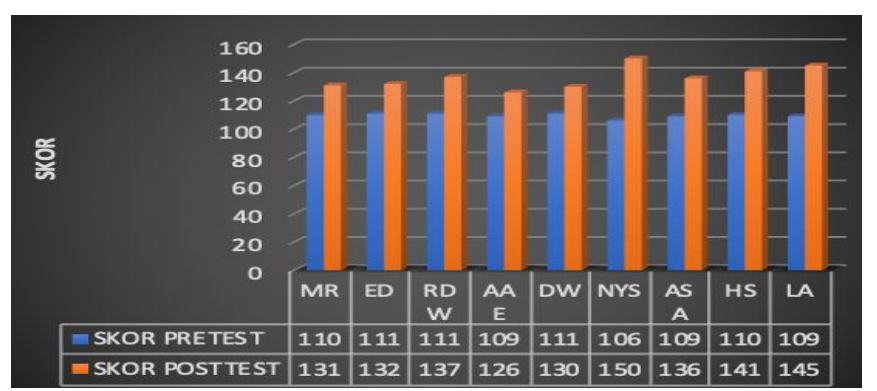

\section{Gambar 1. Perbedaan Skor Pretest dan Postest Subjek Pelatihan}

Pada Gambar 1 dapat dilihat bahwa terdapat perbedaan skor antara pretest dan postest pada masing-masing subjek. Terlihat pula pada gambar/grafik tersebut perbedaan 
nilai skor pas- cates lebih besar dari nilai skor prates. Perbedaan ini menunjukan bahwa setelah diberi konseling kelompok AT terjadi peningkatan keterampilan komunikasi interpersonal untuk semua subjek. Pemberian perlakuan dilakukann oleh peneliti selama 6 kali pertemuan menggunakan metode Quasi Eksperiment, dengan menggunakan pola Pre-test dan Post-test Group yang disesuaikan dengan tahapan konseling kelompok dengan pendekatan AT.

Tahap selanjutnya adalah pengujian hipotesis, untuk mengetahui meningkat atau tidaknya data yang signifikan pada skor keterampilan komunikasi interpersonal mahasiswa. Jumlah skor pretest dan posttest dengan dianalisis menggunakan uji Wilcoxon Sign Rank Test. Adapun perhitungannya pada table 1.

Tabel 1. Hasil uji wilcoxon

Test Statisticsa

\begin{tabular}{ll}
\hline$Z$ & Sesudah - Sebelum \\
\hline Asymp. Sig. (2-tailed) & $-3.182 \mathrm{~b}$ \\
\hline a. Wilcoxon Signed Ranks Test & .001 \\
\hline b. Based on negative ranks. & \\
\hline
\end{tabular}

Dari tabel hasil output Wilcoxon Sign Rank Test diperoleh nilai Sig = (2-tailed) yang berarti $0.001<0.05$ sehingga disimpulkan adanya pengaruh peningkatan keterampilan komunikasi interpersonal mahasiswa calon Guru BK menggunakan konseling kelompok AT pada mahasiswa yang dijadikan sebagai subjek penelitian dalam meningkatkan keterampilan komunikasi interpersonal.

Berdasarkan gambar 1, dapat diketahui bahwa studi pendahuluan pada penelitian ini menunjukkan hasil pengumpulan data awal yang dilakukan melalui pretest skala keterampilan komunikasi interpersonal tersebut ada sekelompok mahasiswa yang menunjukkan keterampilan komunikasi interpersonal dengan klasifikasi rendah yang artinya mahasiswa kurang memiliki keterampilan komunikasi interpersonal, kondisi tersebut tidak dapat diabaikan, karena mahasiswa calon Guru BK perlu memiliki keterampilan komunikasi interpersonal yang baik agar proses interaksi dalam proses konseling dapat berhasil dan memerlukan usaha preventif dan pengembangan.

Adapun aspek keterampilan komunikasi interpersonal yang harus dicapai mahasiswa calon Guru BK ada lima, yaitu kemampuan mendengarkan apa yang disampaikan orang lain, kemampuan memahami orang lain, kemampuan mengkomunikasikan pikiran dan perasaan secara tepat dan jelas, kemampuan saling menerima dan saling memberi dukungan, dan kemampuan memecahkan konflik (Desai, 2018). Hasil penelitian secara umum menunjukkan bahwa kelima aspek keterampilan komunikasi interpersonal berada pada capaian tingkatan yang baik. Artinya, mahasiswa calon Guru BK mampu mendengarkan, mengkomunikasikan menyampaikan dan menerima pesan, serta memecahkan masalah dari perilaku yang ditunjukkan mahasiswa 
secara umum telah mampu mengkomunikasikan dengan baik. Pada prinsipnya, komunikasi merupakan hal yang paling esensial dalam kehidupan manusia, tidak hanya dalam proses konseling (Hariko, 2017). Dengan demikian, komunikasi individu mengekspresikan dirinya, membentuk jaringan sosial dan mengembangkan kepribadiannya (Zamroni, 2009). Kegagalan individu dalam berkomunikasi menghambat terciptanya saling pengertian, kerja sama, toleransi, dan menghambat terlaksananya norma-norma social (Hariko, 2017). Demikian juga apabila dikaitkan dengan konseling, kegagalan atau kesuksesan proses komunikasi berpengaruh besar terhadap hubungan Guru BK dan konseli, serta pengembangan diri dan pengentasan permasalahan pada konseli (Corey, 2015). Oleh karena itu, mahasiswa calon Guru BK secara berkelanjutan diharapkan dapat meningkatkan pemahaman dan penguasaan tentang keterampilan komunikasi interpersonal.

Mahasiswa calon Guru BK yang kurang memiliki keterampilan komunikasi interpersonal disebabkan oleh dominasi status ego anak dalam mendengarkan, mengkomunikasikan menyampaikan dan menerima pesan, serta memecahkan masalah (Husna, 2018). Salah satu faktor yang mempengaruhi tidak memilikinya keterampilan komunikasi interpersonal berdasarkan dari hasil temuan penelitian adalah perlakuan orang tua di masa kecil yang bersikap kasar dalam berkomunikasi, terlalu keras menyampaikan pesan Sehingga anak tidak dapat menerima pesan dengan baik, tidak menghiraukan pendapat anak, terlalu mengkritik presepsi anak yang berdampak pada perkembangan anak, sehingga dalam mengkomunikasikan pesan dengan orang lain mengalami kegagalan dan membuat mahasiswa memiliki sikap "saya oke - kamu tidak oke" dalam berinteraksi dengan lawan bicara. Posisi hidup tersebut menunjukkan adanya kecenderungan pada diri seseorang untuk menuntut seseorang, menyalahkan seseorang, mengkambing hitamkan orang lain, dan menuduh orang lain (Harris, 2012). Hal ini dapat disebabkan karena mereka merasa dikecewakan orang lain. Pada posisi ini individu menganggap dirinya lebih baik dari orang lain.

Melalui penelitian eksperimen dengan konseling kelompok dengan teknik analisis transaksional, semua anggota dalam konseling kelompok dikondisikan dalam pembelajaran mengenai struktur kepribadian dan memfungsikan secara tepat serta dapat menganalisanya sesuai dengan tahapan AT dalam meningkatkan keterampilan komunikasi interpersonal. Pembelajaran ini bertujuan agar semua anggota menyadari dan dapat merubah script yang membawa mereka pada interaksi yang baik. Perubahan yang dilakukan kelompok dalam interaksi dari "saya oke, kamu tidak oke" ke arah "saya oke, kamu oke", hal tersebut merujuk pada peningkatan kemampuan dalam berkomunikasi dari mendengarkan, mengkomunikasikan menyampaikan dan menerima pesan, serta memecahkan masalah agar mampu memiliki keterampilan dalam berinteraksi dengan baik.

Suasana atau kondisi lingkungan yang ada dalam konseling kelompok, memfasilitasi individu untuk dapat berinteraksi dengan orang lain sehingga penelitian ini dapat berhasil, bahwa AT efektif untuk meningkatkan keterampilan komunikasi interpersonal (Chen \& Rybak, 2017). Berdasarkan hasil pelaksanaan treatmen selain mengandalkan data kuantitatif juga menggunakan data kualitatif yang termuat dalam jurnal refleksi diri dan lembar pengalaman anggota kelompok. 
Adapun kegiatan yang dilakukan kelompok eksperimen selama melakukan treatmen, yaitu setiap anggota terlebih dahulu melakukan pengenalan dengan anggota baru yang belum dikenal sebelumnya. Pemimpin kelompok dalam treatmen ini adalah peneliti. Kegiatan ini difasilitasi oleh pemimpin kelompok dengan dua asisten pemimpin kelompok. Treatmen ini dilaksanakan sesuai dengan tahapan yang telah disusun berdasarkan pada tahapan umum dalam konseling kelompok yang dipadukan dengan tahapan yang ada dalam AT, yaitu tahap awal (kontrak), tahap analisis struktural, tahap analisis transaksional, tahap analisis game, tahap analisis script, dan tahap akhir (Corey, 2015; Harris, 2012). Tahap-tahapan tersebut merupakan satu kesatuan dari treatmen yang diikuti anggota kelompok dengan baik, sehingga keberhasilan pelaksanan treatmen efektif dalam meningkatkan keterampilan komunikasi interpersonal.

Pemahaman dasar yang diberikan peneliti, dapat memberikan stimulus kepada anggota terkait dengan menganalisa status ego yang digunakan ketika berada didalam permasalahannya. Pada saat menganalisa status ego, anggota mengungkapkan permasalahannya. Salah satu ucapan anggota yang menunjukkan bahwa anggota telah memahami penempatan status ego yang kurang tepat

"(Terdiam sejenak) mmmm...... pemikiran saya memerintah, perasaan saya tersinggung dengan sikap AAE yang semaunya sendiri tanpa menghargai pemimpin, perilaku saya juga menunjukkan keharusan mengikuti aturan pemimpin. maka status ego yang saya gunakan adalah status ego orang tua bukan status ego anak".

Berdasarkan pemahaman anggota terkait status ego yang kurang tepat, maka hal ini langsung berdampak pada kemampuan mendengarkan apa yang disampaikan orang lain. Dengan demikian, peneliti membantu anggota menempatkan posisi status ego yang tepat terlebih dahulu, karena jika status ego yang digunakan tidak tepat maka dapat berakibat pada rendahnya kemampuan mendengarkan apa yang disampaikan orang lain. Ucapan pembenaran transaksi yang dilakukan salah satu anggota

"agar tidak terjadi perselisihan, sebaiknya saya mengingatkan AAE dengan cara yang halus, karena didalam kelompok perlu adanya kerjasama. Selain itu saya juga tidak boleh bertindak seenaknya sendiri, semua harus dibicarakan dengan anggota yang lain. ya...ini memang salah saya juga".

Berdasarkan ucapan anggota tersebut, telah menunjukkan bahwa status ego yang digunakan adalah dewasa, dan secara langsung perubahan kesadaran diri dalam 
mengakui kesalahan sejalan dengan penempatan status ego yang tepat. Berdasarkan dari konsep teori dan dukungan para peneliti, bahwa Analisis Transaksional yang menekankan aspek kognitif dan perilaku, pencapaian kehidupan otonom yang didefinisikan sebagai kesadaran, spontanitas, dan kapasitas untuk keintiman (Corey, 2015)

Hasil temuan penelitian ini memperbaiki hasil penelitian sebelumnya, yaitu (Bolghanabadi, 2012) mengungkapkan hasil penelitiannya bahwa analisis transaksional bisa menjadi intervensi yang efektif untuk meningkatkan keterampilan pemecahan konflik. Artinya pada tahapan-tahapan yang ada di analisis transaksional telah membantu menyadarkan individu untuk terampil dalam memecahkan konfliknya. Disamping itu, hasil penelitian (Boholst, 2003) membuktikan bahwa konseling kelompok dengan teknik analisis transaksional dapat mempengaruhi perubahan status ego dan presepsi status ego masing-masing.

Temuan peneliti didukung dengan hasil temuan (Nurjanah, 2010) dalam penelitiannya menjabarkan bahwa pendekatan konseling Analisis Transaksional terbukti dapat membantu dalam memperbaiki self esteem negatif pada siswa SMAN 1 Cikalongwetan, dengan indikator ketercapaian dapat terlihat dari perubahan keyakinan mahasiswa dengan menimbulkan kesadaran baru tentang pola-pola atau beberapa keputusan hidup yang dianggap salah di masa lalu. Disamping itu penelitian (Ebrahimisani \& Hashemian, 2012) menunjukkan bahwa terapi kelompok analisis transaksional tidak hanya efektif dalam meningkatkan harga diri tetapi juga meningkatkan perilaku dan hubungan interpersonal.

Dalam pencapaian tujuan dan memperkuat hipotesis, Analisis Transaksional lebih menekankan pada aspek kognitif dan perilaku. Penekanan tersebut terjadi didalam proses transaksi yang berasal dari pengelolaan status ego (pikiran, perasaan, perilaku) yang tepat. Status ego yang dikelolah dalam transaksi dapat mengembangkan psikomotorik mahasiswa. Salah satu bahasan yang lebih kongkret tentang penerapan sejumlah keterampilan komunikasi dikemukakan oleh yaitu: (Nelson-Jones, 2008) (1) komunikasi verbal; (2) komunikasi vokal; (3) komunikasi tubuh; (4) komunikasi sentuhan (touch communication); dan (5) komunikasi mengambil tindakan (taking action communication). Hariko menjelaskan bahwa komunikasi verbal atau percakapan terdiri atas pesan-pesan yang dikirim oleh Guru BK kepada konseli dengan menggunakan katakata (Hariko, 2017). Selanjutnya, dimensi komunikasi verbal meliputi bahasa, isi, frekuensi pembicaraan, dan kepemilikan atas perbendaharaan kata-kata dalam berinteraksi. Dimensi bahasa tidak hanya meliputi jenis bahasa, tetapi juga mencakup elemen seperti gaya bahasa formal atau informal yang digunakan, misalnya gaya bahasa Guru BK yang tepat merangsang terwujudnya proses konseling yang konstruktif (Hariko, 2017). Sementara itu, dimensi isi merujuk pada aspek topik dan bidang permasalahan yang disampaikan oleh konseli. Isi pembicaraan biasanya berfokus pada percakapan dengan orang lain atau lingkungan, dan percakapan di evaluatif. Namun, ada kalanya frekuensi dalam berinteraksi lebih didominasi oleh Guru BK. Terkadang, dalam situasi lain didominasi oleh konseli. Dalam hal ini, Guru BK hendaknya mampu menggunakan kata yang tepat dan memiliki analisis cermat terhadap perbendaharaan kata yang digunakan konseli (Nelson-Jones, 2008). 
Hal ini didukung oleh penelitian (Rajan \& Chacko, 2012) menjelaskan hasil penelitiannya bahwa praktek kesadaran status ego menggunakan model PAC membantu untuk meningkatkan kesadaran diri dan menopang bahkan sampai satu tahun setelah pelatihan. Dengan demikian, treatmen yang diberikan dengan menggunakan AT dapat meningkatkan keterampilan komunikasi interpersonal mahasiswa calon Guru BK.

\section{Kesimpulan}

Pendekatan Konseling kelompok dengan teknik analisis transaksional terbukti efektif meningkatkan keterampilan komunikasi interpersonal mahasiswa calon Guru BK. Perubahan yang dilakukan subjek dalam berinteraksi dari "saya oke, kamu tidak oke" ke arah "saya oke, kamu oke", hal tersebut merujuk pada peningkatan keterampilan dalam berinteraksi dua arah. Hal ini diperkuat dari data hasil output Wilcoxon Sign Rank Test diperoleh nilai Sig $=(2$-tailed $)$ yang berarti $0.001<0.05$ yang artinya adanya pengaruh peningkatan keterampilan komunikasi interpersonal mahasiswa calon konselor setelah dilakukan konseling kelompok AT pada mahasiswa yang dijadikan sebagai subjek penelitian dalam meningkatkan keterampilan komunikasi interpersonal. Bagi peneliti selanjutnya disarankan, lebih memperdalam topik penelitian dengan memperluas subjek dengan pengadaan pelatihan keterampilan komunikasi interpersonal dengan analisis transaksional.

\section{ACKNOWLEDGMENTS}

Peneliti mengucapkan terima kasih kepada LPPM Universitas Kanjuruhan Malang yang telah menyetujui penelitian ini.

\section{DAFTAR RUJUKAN}

Astiti, P., Suminar, J. R., \& Rahmat, A. (2018). Konstruksi Identitas Guru Bimbingan Konseling sebagai Komunikator Pendidikan. Jurnal Kajian Komunikasi, 6(1), 1-9.

Boholst, F. A. (2003). Effects of transactional analysis group therapy on ego states and ego state perception. Transactional Analysis Journal, 33(3), 254-261.

Bolghanabadi, M. (2012). Effectiveness of Cognitive and Transactional Analysis Group Therapy on Improving Conflict-Solving Skill. Zahedan Journal of Research in Medical Sciences, 14(1), 43-48.

Chen, M., \& Rybak, C. (2017). Group leadership skills: Interpersonal process in group counseling and therapy. SAGE Publications.

Corey, G. (2009). Theory and Practice of Counseling and Psychotherapy, Eight Edition. USA: Brooks/Cole, Cengage Learning.

Corey, G. (2015). Theory and practice of counseling and psychotherapy. Nelson Education.

Creswell, J. W., \& Creswell, J. D. (2017). Research Design: Qualitative, Quantitative, and Mixed Methods Approaches. Thousand Oaks, CA: Sage Publications.

Desai, M. (2018). Module 5 Sensitive Interpersonal Communication Skills. In Introduction to Rights-based Direct Practice with Children (pp. 129-150). Springer. 
Ebrahimisani, E., \& Hashemian, K. (2012). The effectiveness of transactional analysis group therapy in increasing the self-esteem of Northern Khorasan province prisons' soldier-guards. Journal Mil Med, 14(3), 214-220.

Geldard, R. G. (2005). Essential Transcendentalists. Penguin.

Gumilang, G. S. (2016). Evaluasi Keterampilan Komunikasi Interpersonal Antara Konselor Dengan Siswa, Staf Sekolah, dan Orangtua SMKN di Kota Malang. JKI (Jurnal Konseling Indonesia), 1(2), 76-82.

Hapsyah, D. R., Fitriyani, N., Handayani, R., Nurmalia, T., Jabbar, A. A., Purwanto, D., \& Badrujaman, A. (2019). Hubungan Antara Sikap Terhadap Evaluasi Guru BK dengan Keterlaksanaan Progam Bimbingan dan Konseling. Jurnal Renaissance, 4(02), 564-571.

Hariko, R. (2017). Landasan Filosofis Keterampilan Komunikasi Konseling. Jurnal Kajian Bimbingan Dan Konseling, 2(2), 41-49.

Harris, T. A. (2012). I'm OK, you're OK. Random House.

Huang, Y. C., \& Lin, S. H. (2018). An inventory for assessing interpersonal communication competence of college students. British Journal of Guidance and Counselling, 46(4), 385401. https://doi.org/10.1080/03069885.2016.1237614

Husna, N. (2018). Dampak Media Sosial terhadap Komunikasi Interpersonal Pustakawan di Perpustakaan UIN Sunan Kalijaga Yogyakarta. LIBRIA, 9(2), 183-196.

Irawan, S. (2017). Pengaruh konsep diri terhadap komunikasi interpersonal mahasiswa. Scholaria: Jurnal Pendidikan Dan Kebudayaan, 7(1), 39-48.

Lopes, R. C. C., Azeredo, Z. de A. S., \& Rodrigues, R. M. C. (2013). Interpersonal Communication Assessment Scale: Psychometric Study of the Portuguese Version. Journal of Professional Nursing, 29(1), 59-64. https://doi.org/https://doi.org/10.1016/j.profnurs.2012.04.010

Maulana, M. A., \& Hidayati, A. (2016). Penggunaan Layanan Bimbingan Kelompok Teknik Diskusi untuk Meningkatkan Kemampuan Komunikasi Interpersonal Mahasiswa Bimbingan dan Konseling Univet Bantara Sukoharjo Angkatan Tahun 2015/2016. Edudikara: Jurnal Pendidikan Dan Pembelajaran, 1(1), 67-72.

Nagarajan, D. P., \& Dr.G.Wiselin, J. (2010). Online Educational System (e- learning) . International Journal of $U$ - and e-Service, Science and Technology, 3(4), 37-48.

Nelson-Jones, R. (2008). Introduction to counselling skills: Text and activities. Sage.

Nurjanah, N. (2010). Efektivitas Konseling Analisis Transaksional untuk Meningkatkan Self Esteem Siswa (Studi Kasus Terhadap Siswa SMAN 1 Cikalongwetan Kabupaten Bandung Barat). Tesis.

Palupi, J., Hidayat, M. F., Subiyantini, D., \& Rizki, P. (2016). Keterampilan Komunikasi Interpersonal Mahasiswa Tingkat Satu. Retrieved from Eprints. Umk. Ac. Id/6115/5/3_Ketrampilan_Komunikasi.Pdf.

Permatasari, D. (2015). Menumbuhkan Kerendahan Hati Siswa SMP Melalui Konseling Kelompok Analisis Transaksional. Proceedings Konferensi Nasional" Mempersiapkan Kebangkitan Generasi Emas Indonesia 2045 Melalui Revolusi Mental Anak Bangsa", 1(1), 325-343.

Qalbas, R. (2018). Pengaruh Komunikasi Interpersonal Guru dalam meningkatkan Kedisiplinan Siswa MTsN 1 Indrapuri Aceh Besar. (Doctoral Disertation, UIN Ar-Raniry Banda Aceh).

Radjah, C. (2016). Keterampilan Konseling Berbasis Metakognisi. Jurnal Kajian Bimbingan Dan Konseling, 1(3), 90-94. https://doi.org/10.17977/um001v1i32016p090 
Rajan, M., \& Chacko, T. (2012). Improving educational environment in medical colleges through transactional analysis practice of teachers. F1000Research, 1.

Riswanto, D., Mappiare-AT, A., \& Irtadji, M. (2016). Karakteristik kepribadian ideal konselor (studi hermeneutika gadamerian). Jurnal Pendidikan: Teori, Penelitian, Dan Pengembangan, 1(11), 2113-2117.

Saaranen, T., Vaajoki, A., Kellomäki, M., \& Hyvärinen, M.-L. (2015). The simulation method in learning interpersonal communication competence-Experiences of masters' degree students of health sciences. Nurse Education Today, 35(2), e8-e13. https://doi.org/https://doi.org/10.1016/j.nedt.2014.12.012

Sari, T. D., \& Widyastuti, A. (2016). Hubungan antara kecerdasan emosi dengan kemampuan manajemen konflik pada istri. Jurnal Psikologi, 11(1), 49-54.

Simon, I. M. (2011). Penerapan Model Experiential Learning sebagai Strategi untuk Meningkatkan Kemampuan Coping Self-Talk bagi Calon Konselor.(Tesis). DISERTASI Dan TESIS Program Pascasarjana UM.

Sukarno, B. (2017). Komunikasi Interpersonal Keluarga Sebagai Mediasi Perlindungan Perempuan Dan Anak Dari Kekerasan. Research Fair Unisri, 1(1).

Sundah, A. J. (2018). The Effectiveness of Transactional Analysis Counseling to Increase Self Esteem. International Journal of Scientific Research and Management, 6(4), 266.

Suprihatin, S. (2017). Kompetensi Profesional Guru Bimbingan dan Konseling Dalam Pelayanan Bimbingan dan Konseling. JIGC, 1(1), 14-26.

Vahabi, B., Vahabi, A., \& Roshani, D. (2017). A study of interpersonal communication skills and its associated factors among students of Kurdistan University of Medical Sciences, 2015. Journal of Medical Education Development, 9(24), 102-112.

Wijaya, A. A., \& Naryoso, A. (2017). Komunikasi Interpersonal Lintas Generasi Untuk Menghadapi Stres Akademik Pada Anak. Interaksi Online, 18(2), 1-7.

Wulandari, N. W. (2019). Interaksi Sosial Dan Kecerdasan Moral Pada Remaja. WACANA, 11(2), 185-195.

Zamroni, M. (2009). Perkembangan Teknologi Komunikasi dan Dampaknya Terhadap Kehidupan. Jurnal Dakwah, 10(2), 195-211. 